\title{
Genetic Mouse Models of Parkinsonism: Strengths and Limitations
}

\author{
Sheila M. Fleming, Pierre-Olivier Fernagut, and Marie-Françoise Chesselet \\ Departments of Neurology and Neurobiology, The David Geffen School of Medicine, UCLA, Los Angeles, California 90095
}

\begin{abstract}
Summary: Parkinson's disease (PD) is a progressive neurodegenerative disorder. Patients with PD display a combination of motor symptoms including resting tremor, rigidity, bradykinesia, and postural instability that worsen over time. These motor symptoms are related to the progressive loss of dopamine neurons in the substantia nigra pars compacta. PD patients also suffer from nonmotor symptoms that may precede the cardinal motor symptoms and that are likely related to pathology in other brain regions. Traditional toxin models of PD have focused on the nigrostriatal pathway and the loss of dopamine
\end{abstract}

neurons in this region, and these models have been important in our understanding of PD and in the development of symptomatic treatments for the disease. However, they are limited in that they do not reproduce the full pathology and progression seen in PD, thus creating a need for better models. The recent discovery of specific genes causing familial forms of PD has contributed to the development of novel genetic mouse models of PD. This review discusses the validity, benefits, and limitations of these new models. Key Words: $\alpha$-Synuclein, parkin, DJ-1, Nurr1, Pitx3, mice.
Parkinson's disease (PD) is one of the most common neurodegenerative disorders. PD is primarily characterized by the loss of dopamine (DA) neurons in the substantia nigra and the development of proteinacious neuronal inclusions called Lewy bodies. Typically at the time of diagnosis, patients suffer from motor impairments, including bradykinesia, tremor, rigidity, and postural instability that worsen as the disease progresses. These motor symptoms are associated with the progressive loss of nigrostriatal DA neurons. In addition, patients also suffer from nonmotor symptoms such as olfactory impairments, gastrointestinal dysfunction, depression, sleep disturbances, and cognitive impairments that are likely related to alterations in brain regions other than the substantia nigra and may precede the cardinal motor symptoms. ${ }^{1-3}$ Although most cases of PD are sporadic, the recent discovery of specific mutations in genes that cause familial forms of PD has led to a new approach in the study of PD. Several genes including $\alpha$-synuclein, parkin, DJ-1, UCHL1, Pink1, and most recently LRRK $2^{4-13}$ have been implicated in familial PD (Table 1). In addition, the discovery of genes essential

Address correspondence and reprint requests to Marie-Françoise Chesselet, M.D., Ph.D, Departments of Neurology and Neurobiology, The David Geffen School of Medicine at UCLA, 710 Westwood Plaza, Los Angeles, CA 90095-1769. E-mail: Mchesselet@mednet.ucla.edu. for the development of DA neurons has provided clues to the susceptibility of DA neurons in PD. Both approaches have led to the generation of novel animal models: genetic mouse models of PD.

\section{$\alpha$-SYNUCLEIN MICE}

$\alpha$-Synuclein (PARK 1) was the first gene to be linked with PD when two missense mutations (A30P and A53T) were identified in familial PD. ${ }^{6,8}$ This discovery led to the identification of $\alpha$-synuclein as being one of the major components of Lewy bodies and glial cytoplasmic inclusions in sporadic PD, dementia with Lewy bodies, and multiple system atrophy. Based on this common cytopathological hallmark, these movement disorders are now classified as synucleinopathies. ${ }^{14}$ Functionally, $\alpha$-synuclein (PARK 1) is a 140 -amino acid presynaptic protein notably involved in vesicle handling and neurotransmitter release. ${ }^{15,16}$

The identification of a third mutation $(\mathrm{E} 46 \mathrm{~K})^{17}$ and more recently of genomic multiplications (duplication or triplication) of a locus containing the $\alpha$-synuclein gene in several PD families ${ }^{9,18,19}$ further highlights the importance of endogenous $\alpha$-synuclein in the disease. Even though there is so far no direct relationship between sporadic PD and $\alpha$-synuclein expression, the existence of several polymorphisms in the promoter of the $\alpha$-synuclein gene 
TABLE 1. Identified Genes Associated with Familial Parkinson's Disease

\begin{tabular}{llllr}
\hline Park & \multicolumn{1}{c}{ Locus } & \multicolumn{1}{c}{ Gene } & \multicolumn{1}{c}{ Function } & References \\
\hline Park 1 & 4q21-22 & Q-Synuclein & Presynaptic & 8 \\
Park 2 & 6q25-27 & Parkin & E3 ubiquitin ligase & 5 \\
Park 5 & 4p14 & UCH-L1 & Ubiquitin recycling enzyme & 10 \\
Park 6 & 1p25-36 & PINK1 & Mitochondrial & 11 \\
Park 7 & 1p36 & DJ1 & Oxidative stress response & 4 \\
Park 8 & 12p11.2q13.1 & LRRK2 & Kinase & 12 \\
\hline
\end{tabular}

suggests that expression levels might be a risk factor. ${ }^{20-22}$ Given the widespread occurrence of $\alpha$-synuclein aggregation in sporadic synucleinopathies, and the pathogenic role of increased endogenous $\alpha$-synuclein in familial forms of PD due to genomic multiplications, $\alpha$-synuclein has been the focus of an increasing number of investigations aimed at elucidating its pathophysiological significance.

Several transgenic mouse lines including $\alpha$-synuclein knockout or overexpression of human $\alpha$-synuclein (wildtype, A30P, A53T or A30P+A53T) have been generated. $\alpha$-Synuclein knockout mice show reduced rearing activity in the open field, decreased DA content in the striatum, ${ }^{23}$ and a decrease of the reserve pool of vesicles in the hippocampus. ${ }^{15}$ More recently, a double knockout for $\alpha$ - and $\beta$-synuclein shows a similar reduction in striatal DA. ${ }^{24}$ These results confirm in vivo the fine regulatory role of $\alpha$-synuclein in synaptic plasticity and vesicle maintenance. Interestingly, several lines of $\alpha$-synuclein null mice have a complete ${ }^{25}$ or partial $^{26,27}$ resistance to the neurotoxin 1-methyl-4-phenyl-1,2,3,6tetrahydropyridine (MPTP).

Overexpression of human $\alpha$-synuclein in mice results in variable neuropathological and behavioral phenotypes, and expression levels can be estimated to range from 0.5-30 fold compared with endogenous $\alpha$-synuclein. ${ }^{28-36}$ Interestingly, the most pronounced phenotypes are consistently observed in the highest expressing lines, regardless of the promoter used to drive the transgene. This supports the emerging idea that expression levels can play a significant role in the disease progression and manifestation. ${ }^{9}$

Several lines of $\alpha$-synuclein overexpressing mice show pathology in areas such as the spinal cord and in neuromuscular junctions ${ }^{29-32}$ and no pathology in the nigrostriatal pathway. Of the many different $\alpha$-synuclein overexpressing mice generated, only a few show alterations in the nigrostriatal DA system (Tables 2 and 3). ${ }^{33-35}$ Although none of the transgenic lines initially reported a loss in dopaminergic neurons, mice overexpressing the doubly mutated $\mathrm{A} 30 \mathrm{P}+\mathrm{A} 53 \mathrm{~T} \alpha$-synuclein under the $\mathrm{TH}$ promoter present a progressive reduction of striatal dopamine transporter (DAT) density and reduced DA and metabolite levels. ${ }^{33}$ Subsequently, it was shown that these mice do have a progressive loss of Nissl-stained neurons in the substantia nigra at 8.5 and
19 months, but the number of TH-positive neurons remains stable. ${ }^{37}$ Compatible with this pathology, these mice show age-related motor impairments including decreased locomotor activity and increased righting time on an inverted screen. ${ }^{33}$ These mice also show a reduced response to the dopaminergic agonists apomorphine and amphetamine. ${ }^{33,37}$ Similarly, mice that overexpress wildtype human $\alpha$-synuclein under the PDGF $\beta$ promoter show reduced TH activity and DA content in the striatum and behaviorally they have impaired performance on the rotarod. $^{35}$

In mice overexpressing human wild-type $\alpha$-synuclein under the Thy 1 promoter, $\alpha$-synuclein overexpression is widespread throughout the brain including cortex, substantia nigra, and olfactory areas ${ }^{34}$ and proteinase Kresistant inclusions and increased microglia are found in the substantia nigra (Hutson, C. B., P.-O. Fernagut, and M.-F. Chesselet, unpublished observations). In these mice, the substantia nigra is vulnerable to subtoxic doses of MPTP, ${ }^{38}$ and they show a wide range of progressive sensorimotor impairments including impaired performance on a challenging beam, impairments orienting on a pole, decreased spontaneous activity, altered response to sensory stimuli, and impairments in fine motor skills. ${ }^{39}$ These impairments progressively worsen with age and can be detected as early as 2 months. ${ }^{39}$ These mice have a small but significant decrease in DAT and vesicular monoamine transporter (VMAT) binding in the striatum at 8 months (Fernagut, P.-O., and M.-F. Chesselet, unpublished observations). Similar to the A30P + A53T $\alpha$-synuclein mice, the Thy $1 \alpha$-synuclein mice show an abnormal behavioral response to dopaminergic agonists including L-DOPA, apomorphine, and amphetamine (Fleming, S. M., J. Salcedo, C. B. Hutson, E. Rockenstein, E. Masliah, M. S. Levine, and M.-F. Chesselet, submitted). Notably, they show a marked decrease in amphetamine-induced stereotypies, but increases in sensitivity to low doses of apomorphine. In addition, these mice also show impairments in olfaction and gastrointestinal function; both impairments are associated with the nonmotor symptoms seen in PD and provide further support for $\alpha$-synuclein's involvement in PD (Fleming, S. M., L. Wang, Y. Tache, and M.-F. Chesselet, unpublished observations). 
TABLE 2. Nigrostriatal Pathology in Genetic Mouse Models of PD

\begin{tabular}{|c|c|c|c|}
\hline Mouse & Mutation & DA Pathology & References \\
\hline \multirow[t]{3}{*}{$\begin{array}{l}\alpha \text {-Synuclein } \\
\quad \text { overexpressor }\end{array}$} & A53T + A30P: TH promoter & $\begin{array}{l}\downarrow \text { Striatal DA, DOPAC, HVA, } \downarrow \text { striatal } \\
\text { DAT, } \downarrow \text { SNc neurons }\end{array}$ & 33,37 \\
\hline & $\begin{array}{l}\text { Human wild type: PDGF } \beta \\
\text { promoter }\end{array}$ & $\begin{array}{l}\downarrow \text { TH activity in striatum, } \downarrow \text { striatal } \\
\text { DA content }\end{array}$ & 35 \\
\hline & $\begin{array}{l}\text { Human wild type: Thy1 } \\
\text { promoter }\end{array}$ & $\begin{array}{l}\uparrow \text { SNc Vulnerability to MPTP, } \downarrow \\
\text { striatal DAT and VMAT }\end{array}$ & $\begin{array}{l}\text { 34, 38; Fernagut, P.-O., } \\
\text { and M.-F. Chesselet, } \\
\text { unpublished } \\
\text { observations }\end{array}$ \\
\hline \multirow[t]{5}{*}{ Parkin knockout } & Exon 3 deletion & $\begin{array}{l}\uparrow \mathrm{DA} ; \downarrow \text { amphetamine induced DA } \\
\text { release; } \downarrow \text { DAT; inhibition of } \\
\text { glutamate transmission }\end{array}$ & 51 \\
\hline & Exon 3 deletion & $\begin{array}{l}\uparrow \text { Extracellular DA; reduced synaptic } \\
\text { excitability in striatal medium spiny } \\
\text { neurons; mitochondrial dysfunction }\end{array}$ & 52,55 \\
\hline & Exon 7 deletion & $\begin{array}{l}\downarrow \text { NE in olfactory bulb and spinal cord; } \\
\downarrow \text { TH-positive neurons in LC }\end{array}$ & 53 \\
\hline & Exon 2 deletion & None detected & 54 \\
\hline & $\begin{array}{l}\text { Spontaneous (Quaking } \\
\text { mouse) }\end{array}$ & $\begin{array}{l}\uparrow \text { DA metabolism; } \uparrow \text { D2 DA receptor } \\
\text { striatal membranes }\end{array}$ & 60 \\
\hline DJ-1 knockout & Exon 2 & $\begin{array}{l}\downarrow \text { Evoked DA overflow in striatum, } \downarrow \\
\text { sensitivity on SNc neurons to D2 } \\
\text { agonist, lack of LTD in striatal } \\
\text { medium spiny neurons }\end{array}$ & 74 \\
\hline DJ-1 knockout & Exon 1 stop codon & $\uparrow \mathrm{SNc}$ vulnerability to MPTP & 75 \\
\hline Nurr1 heterozygote & Reduced Nurr1 & $\begin{array}{l}\downarrow \text { Striatal DA content, } \downarrow \text { SNc neurons, } \\
\uparrow \text { SNc vulnerability to MPTP }\end{array}$ & 80,82 \\
\hline Pitx3-aphakia & Loss of Pitx3 & $\begin{array}{l}\downarrow \text { Striatal DA content, } \downarrow \text { SNc neurons, } \\
\text { L-DOPA-mediated induction of c-fos }\end{array}$ & $61,83,84$ \\
\hline
\end{tabular}

$\mathrm{SNc}=$ substantia nigra pars compacta; $\mathrm{NE}=$ norepinephrine; $\mathrm{TH}=$ tyrosine hydroxylase; $\mathrm{LC}=$ locus coeruleus; $\mathrm{LTD}=$ long-term depression; HVA = homovanillic acid.

Despite the lack of a massive loss of DA nigrostriatal neurons, the $\alpha$-synuclein overexpressing mice with alterations in the nigrostriatal system are useful models of PD because they have mutations that are similar to those found in familial PD, thus giving them construct validity. These mice also have face validity because they have pathology and behavioral impairments reminiscent of the pathology and symptoms observed in the disease. Furthermore, similar to PD, the $\alpha$-synuclein mice with nigrostriatal alterations, have impairments that worsen with age. They will be particularly useful to study the etiology of PD and in understanding the interaction between environmental and genetic factors in relation to PD. In addition, the benefit of a model without nigrostriatal DA loss is that the early stages of the disease, before the loss of nigrostriatal DA neurons, can be studied. Several of these models have a modest loss of DAT and VMAT in the striatum, indicating early stages of DA pathology. ${ }^{40,41}$ In addition, the abnormal response to DA agonists observed in these mice ${ }^{33,37}$ further suggests that they may represent a model of early dopaminergic dysfunction. Moreover, some lines of $\alpha$-synuclein overexpressing mice show neuronal death outside the substantia nigra and/or premature death ${ }^{29,30}$ making them suitable for testing neuroprotective strategies (Table 4).

\section{PARKIN KNOCKOUT MICE}

Soon after the discovery of $\alpha$-synuclein mutations associated with familial PD, it was shown that loss of function mutations in the parkin gene are linked to familial autosomal recessive juvenile PD. The typical age of onset in autosomal recessive juvenile PD is less than 50 years, and patients suffer from motor symptoms similar to idiopathic PD including rigidity, resting tremor, and bradykinesia. Patients respond to L-DOPA therapy; however, they develop L-DOPA-induced dyskinesias sooner than patients with idiopathic PD. ${ }^{42}$ Pathologically, patients also have a degeneration of nigrostriatal DA neurons but most do not develop Lewy bodies. ${ }^{43-46}$

Parkin (PARK 2) is a 465-amino acid protein that acts functionally as an E3 ligase and is involved in the ubiquitination of proteins for degradation by the proteasome. ${ }^{47-49}$ It is thought that mutations causing a loss of parkin function can lead to the abnormal accumulation of parkin substrates. These substrates include glycosylated $\alpha$-synuclein, ${ }^{48}$ synphilin- $1,{ }^{50}$ Pael-R, ${ }^{47}$ and CDCrel- $1^{49}$ and may play an important role in the development of the disease. Knocking out parkin function in mice has been 
TABLE 3. Behavioral Anomalies in Genetic Mouse Models of PD

\begin{tabular}{|c|c|c|c|c|}
\hline Mouse & Mutation & Behavioral Impairments & Effect of DA Agonists & References \\
\hline \multirow[t]{3}{*}{$\begin{array}{l}\alpha \text {-Synuclein } \\
\quad \text { overexpresor }\end{array}$} & $\begin{array}{l}\mathrm{A} 53 \mathrm{~T}+\mathrm{A} 30 \mathrm{P}: \mathrm{TH} \\
\text { promoter }\end{array}$ & $\begin{array}{l}\text { Locomotor activity, righting } \\
\text { on an inverted screen }\end{array}$ & $\begin{array}{l}\text { Reduced locomotor response } \\
\text { to amphetamine and } \\
\text { apomorphine }\end{array}$ & 33,37 \\
\hline & $\begin{array}{l}\text { Human wild type: } \\
\text { PDGF } \beta \text { promoter }\end{array}$ & Rotarod & NA & 35 \\
\hline & $\begin{array}{l}\text { Human wild type: } \\
\text { Thy1 promoter }\end{array}$ & $\begin{array}{l}\text { Challenging beam, pole } \\
\text { test, inverted grid, } \\
\text { spontaneous activity, } \\
\text { response to sensory } \\
\text { stimuli, and fine motor } \\
\text { skills (bin cotton use). }\end{array}$ & $\begin{array}{l}\text { Increased sensitivity to } \\
\text { apomorphine, reduced } \\
\text { response to amphetamine }\end{array}$ & $\begin{array}{l}\text { 39; Fleming, S. M., } \\
\text { J. Salcedo, } \\
\text { C. B. Hutson, } \\
\text { E. Rockenstein, } \\
\text { E. Masliah, } \\
\text { M. S. Levine, and } \\
\text { M.-F. Chesselet, } \\
\text { submitted }\end{array}$ \\
\hline \multirow[t]{5}{*}{$\begin{array}{l}\text { Parkin } \\
\text { knockout }\end{array}$} & Exon 3 deletion & $\begin{array}{l}\text { Locomotor activity, } \\
\text { alternation in T-maze }\end{array}$ & $\begin{array}{l}\text { Reduced response to } \\
\text { amphetamine }\end{array}$ & 51 \\
\hline & Exon 3 deletion & $\begin{array}{l}\text { Challenging beam, response } \\
\text { to sensory stimuli }\end{array}$ & $\begin{array}{l}\text { Decreased grooming response } \\
\text { to intrastriatal DA }\end{array}$ & $\begin{array}{l}\text { 52; Fleming, S. M., } \\
\text { N. T. Maidment, } \\
\text { and M.-F. Chesse- } \\
\text { let, unpublished } \\
\text { observations }\end{array}$ \\
\hline & Exon 7 deletion & Startle response & NA & 53 \\
\hline & Exon 2 deletion & None detected in tests used & $\begin{array}{l}\text { No difference in locomotor } \\
\text { activity after amphetamine }\end{array}$ & 54 \\
\hline & $\begin{array}{l}\text { Spontaneous } \\
\text { (Quaking mouse) }\end{array}$ & Locomotor activity & $\begin{array}{l}\text { Enhanced response to SKF } \\
\text { 38393, Reduced response to } \\
\text { LY 171555 }\end{array}$ & 60 \\
\hline DJ-1 knockout & Exon 2 & Locomotor activity & $\begin{array}{l}\text { Reduced locomotor activity } \\
\text { response to quinpirole }\end{array}$ & 74 \\
\hline DJ-1 knockout & Exon 1 stop codon & None detected in tests used & $\begin{array}{l}\text { Reduced locomotor activity } \\
\text { response to amphetamine }\end{array}$ & 75 \\
\hline $\begin{array}{l}\text { Nurr1 } \\
\text { heterozygote }\end{array}$ & Reduced Nurr1 & Rotarod, locomotor activity & $\begin{array}{l}\text { Enhanced locomotor activity } \\
\text { after methamphetamine }\end{array}$ & 82 \\
\hline Pitx3-aphakia & Loss of Pitx3 & $\begin{array}{l}\text { Challenging beam, pole } \\
\text { test, and spontaneous } \\
\text { activity }\end{array}$ & Reversal with L-DOPA & 61 \\
\hline
\end{tabular}

$\mathrm{NA}=$ not assessed.

accomplished by deletion of exon $3,,^{51,52}$ exon $7,,^{53}$ or exon $2^{54}$ in the parkin gene (Tables 2 and 3 ).

Deletion of exon 3 in parkin results in the absence of the parkin protein. In mice expressing this mutation, ${ }^{51,52}$ there is no overt loss of TH-positive neurons in the substantia nigra or their projections to the striatum; however, more subtle nigrostriatal DA alterations have been shown. Parkin knockout mice with an exon 3 deletion have increased extracellular striatal DA, reduced synap- tic excitability in striatal medium spiny neurons, and progressive sensorimotor impairments including increased errors while traversing a challenging beam and alterations in their response to sensory stimuli. ${ }^{52}$ In addition, these parkin knockout mice show a reduction in weight gain, reduced mitochondrial respiration, reduced antioxidant capacity, and increased oxidative damage in the ventral midbrain. ${ }^{55}$ Similarly, in a separate study, another line of mice with an exon 3 deletion of parkin

TABLE 4. Construct, Face, and Predictive Validity in Genetic Mouse Models of Parkinson's Disease

\begin{tabular}{|c|c|c|c|c|}
\hline Mouse & $\begin{array}{l}\text { Construct } \\
\text { (Etiology) }\end{array}$ & $\begin{array}{c}\text { Face (Symptoms } \\
\text { and Pathology) }\end{array}$ & $\begin{array}{l}\text { Predictive (Response to } \\
\text { Symptomatic Treatment) }\end{array}$ & $\begin{array}{c}\text { Predictive (Testing } \\
\text { Neuroprotection Strategies) }\end{array}$ \\
\hline$\alpha$-Synuclein overexpressor & Good & Good & Poor & Good \\
\hline Parkin knockout & Good & Weak & Poor & Good \\
\hline DJ-1 knockout & Good & Weak & Poor & Good \\
\hline Nurr1 heterozygote & Weak & Good & NA & Good \\
\hline Pitx3-aphakia & Poor & Good & Good & Poor \\
\hline
\end{tabular}

$\mathrm{NA}=$ not assessed. 
show an inhibition of amphetamine-induced DA release in fetal midbrain cultures, inhibition of glutamate transmission in the hippocampus, reduced DAT protein in the striatum, and motor and cognitive deficits including reduced locomotor activity and decreased spontaneous alternation in the T-maze. ${ }^{51}$

Targeted disruption of exon 7 in parkin also results in the loss of parkin function. ${ }^{53}$ Parkin knockout mice with an exon 7 deletion appear to show a different phenotype compared with exon 3 deleted mice; however, they have not been examined in the same comprehensive battery of behavioral tests. Exon 7 parkin knockout mice show reduced acoustic startle response and a loss of TH-containing neurons in the locus coeruleus, which likely occurs during development. In addition, these mice show reduced norepinephrine levels in olfactory bulb and spinal cord. Similar to exon 3 deleted mice, there is no loss of nigrostriatal DA neurons. This is the only parkin knockout mouse to show neuronal loss in the locus coeruleus, and degeneration in this area is a feature of $\mathrm{PD}^{56}$

Similar to both exon 3 and exon 7 deletions, deletion of parkin exon 2 results in the loss of function of parkin. ${ }^{54}$ These mice show no loss of nigrostriatal DA neurons; however, unlike the previously mentioned parkin knockout mice, exon 2-deleted mice show no neuronal loss in the locus coeruleus, no alterations in catecholamine levels and no detectable behavioral impairments. ${ }^{54}$ Although different tests have been used, and DA release or synaptic function have not been measured in these mice, it is possible that either the type of mutation or the genetic background of the mice could contribute to differences in phenotypes between these various lines of mice.

The quaking viable mouse has been known for sometime,${ }^{57}$ it was only recently discovered that these mice also have deletions in parkin and parkin coregulated genes. ${ }^{58,59}$ Similar to exon 3-deleted parkin knockout mice, quaking mice have alterations within the nigrostriatal DA system. ${ }^{60}$ Compared with controls, quaking mice have increased levels of the DA metabolites DOPAC and homovanillic acid in the striatum and olfactory tubercle, respectively, and increased DA D2 receptors. In addition to their quaking phenotype, behaviorally, these mice also show a greater sensitivity to DA D1 receptor agonists and are less sensitive to DA D2 agonist treatment. ${ }^{60}$

Despite the lack of accumulation of parkin substrates in parkin knockout mice, their DA phenotype makes them useful in the study of PD. Like $\alpha$-synuclein mice, parkin knockout mice have a mutation similar to that found in familial PD, which gives them construct validity. This model has face validity because parkin knockout mice show similar behavioral impairments compared to both $\alpha$-synuclein overexpressing mice and mice with known loss of nigrostriatal DA neurons (Pitx3-aphakia mice). ${ }^{39,61}$ Both exon 3 and exon 7 deleted parkin knockout mice may be most beneficial in the understanding of the etiology and the early stages of PD, and in the interaction between environmental and genetic factors associated with the disease. The model is limited by the absence of loss of nigrostriatal DA neurons. In addition, the behavioral phenotype of these mice is modest compared to $\alpha$-synuclein overexpressing, and Pitx3-aphakia mice (see below). However, they show chronic changes in DA release and synaptic dysfunction in the striatum, indicating that they are useful to identify the early effects of a PD-causing mutation in vivo (Table 4).

\section{DJ-1 KNOCKOUT MICE}

Deletion (exons 1-5) or point mutation in DJ-1 have been recently linked to autosomal recessive early onset parkinsonism in two families ${ }^{4}$ and other mutations in the DJ-1 gene have been identified in several cases of early onset parkinsonism. ${ }^{62-64}$ However, DJ-1 mutations appear to be less frequent than parkin mutations. ${ }^{64} \mathrm{DJ}-1$ is only rarely detected in Lewy bodies. ${ }^{65}$ DJ-1 (PARK 7; 189-amino acid protein) appears to be a multifunctional protein as it was initially identified as an oncogene product, ${ }^{66}$ then as a regulatory subunit of a RNA binding protein, ${ }^{67}$ and has been implicated in the cellular response to oxidative stress. ${ }^{68,69}$ Given the multiple functions of DJ-1, especially its involvement in oxidative stress, it may play a role in the pathophysiology of PD. Indeed, deficits in complex 1, decreased antioxidant defenses, and oxidative stress have all been linked to sporadic PD. ${ }^{70}$ Downregulation or knockout of endogenous DJ-1 in vitro increases the vulnerability to oxidative stress and proteasome inhibition. ${ }^{71,72}$ DJ-1 also has a redox-dependant chaperone function and inhibits the aggregation of $\alpha$-synuclein. ${ }^{73}$

Recently, mice with a targeted deletion of exon $2,{ }^{74}$ or insertion of a premature stop codon in exon $1^{75}$ of the DJ-1 gene have been generated (Tables 2 and 3). Similar to $\alpha$-synuclein and parkin knockout mice, DJ-1 knockout mice do not lose nigrostriatal DA neurons. ${ }^{74,75}$ Deletion of DJ-1 exon two has subtle effects on the nigrostriatal pathway. Although TH activity, mRNA expression, and dopamine and its metabolites were unaltered in these mice, evoked dopamine release on striatal slices was clearly reduced, most likely as a consequence of increased reuptake. Nigral neurons from DJ-1 exon $2 \mathrm{mu}-$ tant mice were less responsive to D2 autoreceptor stimulation and were not more vulnerable to paraquat intoxication. Behaviorally, mutant mice showed decreased locomotor activity. Loss of DJ-1 function through insertion of a premature stop codon in exon $1 \mathrm{did}$ not affect the number dopaminergic neurons or their fiber density in the striatum. Reduced locomotor activity was revealed only upon methamphetamine or MPTP chal- 
lenge. In vitro, primary cortical neurons from DJ-1 mutant mice were more sensitive to oxidative stress, and mesencephalic neurons were more sensitive to rotenone. ${ }^{75}$ DJ-1 mutant mice also had an increased sensitivity to MPTP, both at the level of dopaminergic neuronal loss and TH loss in the striatum. This was rescued by restoring DJ-1 expression in mutant mice, further indicating a role for DJ-1 in oxidative stress response. ${ }^{75}$ Similar to $\alpha$-synuclein overexpressing and parkin knockout mice, DJ-1 knockout mice have good construct validity. This model should be of interest to explore the function of DJ-1 in vivo and its potential relevance to sporadic PD (Table 4).

\section{NURR1 AND PITX3-APHAKIA MICE}

Nurr1 is a member of the nuclear receptor superfamily $^{76}$ and is involved in the differentiation and development of nigrostriatal DA neurons. Mutations in Nurr1 alter transcription of the gene that encodes tyrosine hydroxylase $^{77}$ and transcription of the dopamine transport$\mathrm{er}^{78}$ and suggests that alterations in Nurr1 may cause chronic DA alterations that could increase susceptibility to PD. Indeed, it has been shown that mutations in Nurr1 may be associated with familial PD. ${ }^{79}$ Nurr1 is essential for the development of ventral mesencephalon DA neurons as homozygous Nurr1 knockout mice do not develop DA neurons in the substantia nigra and die soon after birth. ${ }^{80}$ In contrast, heterozygous Nurr1 knockout mice do survive and show normal levels of nigrostriatal DA neurons, but they do exhibit a vulnerability to neurotoxins such as MPTP. ${ }^{81}$ More recently, it was shown that, as Nurr1 heterozygous mice age, they develop a decrease in DA levels in the striatum, decreased DA nigrostriatal neurons, and decreased locomotor activity and rotarod performance. ${ }^{82}$ These data indicate a progressive DA phenotype in these mice that bears some resemblance to that found in $\alpha$-synuclein overexpressing and mutant mice..$^{33,35,37,39}$

Similar to Nurr1, Pitx3, a homeobox transcription factor, is involved in the molecular development of nigrostriatal DA neurons. ${ }^{83,84}$ Pitx3-deficient mice (Pitx3aphakia mice $)^{85}$ have a loss of nigrostriatal DA neurons and a $90 \%$ reduction in DA content in the striatum, whereas DA neurons in the ventral tegmental area are spared. ${ }^{84}$ Behaviorally, Pitx3-aphakia mice display sensorimotor impairments on a challenging beam, deficits orienting on a pole, and a decrease in spontaneous rearing. All of these impairments are reversed with L-DOPA treatment. $^{61}$

Both Nurr1 heterozygous and Pitx3-aphakia mice are good models for PD because they have the characteristic loss of nigrostriatal DA neurons. In Nurr1 heterozygous mice, this is even progressive, as in patients (Tables 2 and 3), giving them good face validity. In addition,
Pitx3-aphakia mice have predictive validity for symptomatic treatment in that L-DOPA reverses several of the sensorimotor impairments in these mice. However, these models are limited because they do not reproduce the broad pathology seen in PD and only show pathology in the nigrostriatal pathway (Table 4). Furthermore, it is unclear that the mechanism involved in the cell loss operates in PD. Therefore, their usefulness to test neuroprotective strategies is limited.

Although the DA phenotypes of the $\alpha$-synuclein, parkin knockout, and DJ-1 knockout mice are not as profound as the Nurr1 heterozygous and Pitx3-aphakia mice, they may provide insight into the early stages of the disease. A model of the early stages of PD is an important tool because it allows further investigation into the early events that may lead to the characteristic loss of nigrostriatal DA neurons. Furthermore, animals with known genetic mutations associated with PD can be used to study the mechanisms of the disease and identify therapeutic targets. The Nurr1 and Pitx3-aphakia mice provide good models to study the later stages of the disease and DA neuronal loss that may lead to the development of better symptomatic treatments for PD. Although no perfect animal model of PD exists yet, the mice discussed model complementary aspects of PD and will be important in understanding the etiology and progression of PD.

\section{REFERENCES}

1. Stiasny-Kolster K, Doerr Y, Moller JC, Hoffken H, Behr TM, Oertel WH, Mayer G. Combination of "idiopathic" REM sleep behaviour disorder and olfactory dysfunction as possible indicator for $\alpha$-synucleinopathy demonstrated by dopamine transporter FPCIT-SPECT. Brain 128:126-137, 2005.

2. Ponsen MM, Stoffers D, Booij J, van Eck-Smit BL, Wolters E, Berendse HW. Idiopathic hyposmia as a preclinical sign of Parkinson's disease. Ann Neurol 56:173-181, 2004.

3. Becker G, Muller A, Braune S, Buttner T, Benecke R, Greulich W, Klein W, Mark G, Rieke J, Thumler R. Early diagnosis of Parkinson's disease. J Neurol 249 [Suppl 3]:III40-III48, 2002.

4. Bonifati V, Rizzu P, van Baren MJ, Schaap O, Breedveld GJ, Krieger E, Dekker MC, Squitieri F, Ibanez P, Joosse M, van Dongen JW, Vanacore N, van Swieten JC, Brice A, Meco G, van Duijn CM, Oostra BA, Heutink P. Mutations in the DJ-1 gene associated with autosomal recessive early-onset parkinsonism. Science 299:256-259, 2003.

5. Kitada T, Asakawa S, Hattori N, Matsumine H, Yamamura Y, Minoshima S, Yokochi M, Mizuno Y, Shimizu N. Mutations in the parkin gene cause autosomal recessive juvenile parkinsonism. $\mathrm{Na}$ ture 392:605-608, 1998.

6. Kruger R, Kuhn W, Muller T, Woitalla D, Graeber M, Kosel S, Przuntek H, Epplen JT, Schols L, Riess O. Ala30Pro mutation in the gene encoding $\alpha$-synuclein in Parkinson's disease. Nat Genet 18:106-108, 1998 .

7. Leroy E, Anastasopoulos D, Konitsiotis S, Lavedan C, Polymeropoulos MH. Deletions in the Parkin gene and genetic heterogeneity in a Greek family with early onset Parkinson's disease. Hum Genet 103:424-427, 1998.

8. Polymeropoulos MH, Lavedan C, Leroy E, Ide SE, Dehejia A, Dutra A, Pike B, Root H, Rubenstein J, Boyer R, Stenroos ES, Chandrasekharappa S, Athanassiadou A, Papapetropoulos T, Johnson WG, Lazzarini AM, Duvoisin RC, Di Iorio G, Golbe LI, 
Nussbaum RL. Mutation in the $\alpha$-synuclein gene identified in families with Parkinson's disease. Science 276:2045-2047, 1997.

9. Singleton AB, Farrer M, Johnson J, Singleton A, Hague S, Kachergus J, Hulihan M, Peuralinna T, Dutra A, Nussbaum R, Lincoln S, Crawley A, Hanson M, Maraganore D, Adler C, Cookson MR, Muenter M, Baptista M, Miller D, Blancato J, Hardy J, GwinnHardy K. $\alpha$-Synuclein locus triplication causes Parkinson's disease. Science 302:841, 2003.

10. Wintermeyer P, Kruger R, Kuhn W, Muller T, Woitalla D, Berg D, Becker G, Leroy E, Polymeropoulos M, Berger K, Przuntek H, Schols L, Epplen JT, Riess O. Mutation analysis and association studies of the UCHL1 gene in German Parkinson's disease patients. Neuroreport 11:2079-2082, 2000.

11. Valente EM, Abou-Sleiman PM, Caputo V, Muqit MM, Harvey K, Gispert S, Ali Z, Del Turco D, Bentivoglio AR, Healy DG, Albanese A, Nussbaum R, Gonzalez-Maldonado R, Deller T, Salvi S, Cortelli P, Gilks WP, Latchman DS, Harvey RJ, Dallapiccola B, Auburger G, Wood NW. Hereditary early-onset Parkinson's disease caused by mutations in PINK1. Science 304:1158-1160, 2004.

12. Paisan-Ruiz C, Jain S, Evans EW, Gilks WP, Simon J, van der Brug M, de Munain AL, Aparicio S, Gil AM, Khan N, Johnson J, Martinez JR, Nicholl D, Carrera IM, Pena AS, de Silva R, Lees A, Marti-Masso JF, Perez-Tur J, Wood NW, Singleton AB. Cloning of the gene containing mutations that cause PARK8-linked Parkinson's disease. Neuron 44:595-600, 2004.

13. Zimprich A, Muller-Myhsok B, Farrer M, Leitner P, Sharma M, Hulihan M, Lockhart P, Strongosky A, Kachergus J, Calne DB, Stoessl J, Uitti RJ, Pfeiffer RF, Trenkwalder C, Homann N, Ott E, Wenzel K, Asmus F, Hardy J, Wszolek Z, Gasser T. The PARK8 locus in autosomal dominant parkinsonism: confirmation of linkage and further delineation of the disease-containing interval. Am J Hum Genet 74:11-19, 2004.

14. Spillantini MG, Goedert M. The $\alpha$-synucleinopathies: Parkinson's disease, dementia with Lewy bodies, and multiple system atrophy. Ann NY Acad Sci 920:16-27, 2000.

15. Cabin DE, Shimazu K, Murphy D, Cole NB, Gottschalk W, McIlwain KL, Orrison B, Chen A, Ellis CE, Paylor R, Lu B, Nussbaum RL. Synaptic vesicle depletion correlates with attenuated synaptic responses to prolonged repetitive stimulation in mice lacking $\alpha$-synuclein. J Neurosci 22:8797-8807, 2002.

16. Yavich L, Tanila H, Vepsalainen S, Jakala P. Role of $\alpha$-synuclein in presynaptic dopamine recruitment. J Neurosci 24:11165-11170, 2004.

17. Zarranz JJ, Alegre J, Gomez-Esteban JC, Lezcano E, Ros R, Ampuero I, Vidal L, Hoenicka J, Rodriguez O, Atares B, Llorens V, Gomez Tortosa E, del Ser T, Munoz DG, de Yebenes JG. The new mutation, E46K, of $\alpha$-synuclein causes Parkinson and Lewy body dementia. Ann Neurol 55:164-173, 2004.

18. Ibanez P, Bonnet AM, Debarges B, Lohmann E, Tison F, Pollak P, Agid Y, Durr A, Brice A. Causal relation between $\alpha$-synuclein gene duplication and familial Parkinson's disease. Lancet 364: 1169-1171, 2004.

19. Chartier-Harlin MC, Kachergus J, Roumier C, Mouroux V, Douay X, Lincoln S, Levecque C, Larvor L, Andrieux J, Hulihan M, Waucquier N, Defebvre L, Amouyel P, Farrer M, Destee A. $\alpha$-Synuclein locus duplication as a cause of familial Parkinson's disease. Lancet 364:1167-1169, 2004.

20. Farrer M, Maraganore DM, Lockhart P, Singleton A, Lesnick TG, de Andrade M, West A, de Silva R, Hardy J, Hernandez D. $\alpha$-Synuclein gene haplotypes are associated with Parkinson's disease. Hum Mol Genet 10:1847-1851, 2001.

21. Holzmann C, Kruger R, Saecker AM, Schmitt I, Schols L, Berger $\mathrm{K}$, Riess O. Polymorphisms of the $\alpha$-synuclein promoter: expression analyses and association studies in Parkinson's disease. $\mathrm{J} \mathrm{Neu-}$ ral Transm 110:67-76, 2003.

22. Pals P, Lincoln S, Manning J, Heckman M, Skipper L, Hulihan M, Van den Broeck M, De Pooter T, Cras P, Crook J, Van Broeckhoven C, Farrer MJ. $\alpha$-Synuclein promoter confers susceptibility to Parkinson's disease. Ann Neurol 56:591-595, 2004.

23. Abeliovich A, Schmitz Y, Farinas I, Choi-Lundberg D, Ho WH, Castillo PE, Shinsky N, Verdugo JM, Armanini M, Ryan A, Hynes M, Phillips H, Sulzer D, Rosenthal A. Mice lacking $\alpha$-synuclein display functional deficits in the nigrostriatal dopamine system. Neuron 25:239-252, 2000.

24. Chandra S, Fornai F, Kwon HB, Yazdani U, Atasoy D, Liu X, Hammer RE, Battaglia G, German DC, Castillo PE, Sudhof TC. Double-knockout mice for $\alpha$ - and $\beta$-synucleins: effect on synaptic functions. Proc Natl Acad Sci USA 101:14966-14971, 2004.

25. Dauer W, Kholodilov N, Vila M, Trillat AC, Goodchild R, Larsen KE, Staal R, Tieu K, Schmitz Y, Yuan CA, Rocha M, JacksonLewis V, Hersch S, Sulzer D, Przedborski S, Burke R, Hen R. Resistance of $\alpha$-synuclein null mice to the parkinsonian neurotoxin MPTP. Proc Natl Acad Sci USA 99:14524-14529, 2002.

26. Schluter OM, Fornai F, Alessandri MG, Takamori S, Geppert M, Jahn R, Sudhof TC. Role of $\alpha$-synuclein in 1-methyl-4-phenyl1,2,3,6-tetrahydropyridine-induced parkinsonism in mice. Neuroscience 118:985-1002, 2003.

27. Drolet RE, Behrouz B, Lookingland KJ, Goudreau JL. Mice lacking $\alpha$-synuclein have an attenuated loss of striatal dopamine following prolonged chronic MPTP administration. Neurotoxicology 25:761-769, 2004.

28. Kahle PJ, Neumann M, Ozmen L, Muller V, Jacobsen H, Schindzielorz A, Okochi M, Leimer U, van Der Putten H, Probst A, Kremmer E, Kretzschmar HA, Haass C. Subcellular localization of wild-type and Parkinson's disease-associated mutant $\alpha$-synuclein in human and transgenic mouse brain. J Neurosci 20:6365-6373, 2000 .

29. van der Putten H, Wiederhold KH, Probst A, Barbieri S, Mistl C, Danner S, Kauffmann S, Hofele K, Spooren WP, Ruegg MA, Lin S, Caroni P, Sommer B, Tolnay M, Bilbe G. Neuropathology in mice expressing human $\alpha$-synuclein. J Neurosci 20:6021-6029, 2000.

30. Lee MK, Stirling W, Xu Y, Xu X, Qui D, Mandir AS, Dawson TM, Copeland NG, Jenkins NA, Price DL. Human $\alpha$-synucleinharboring familial Parkinson's disease-linked Ala-53 -> Thr mutation causes neurodegenerative disease with $\alpha$-synuclein aggregation in transgenic mice. Proc Natl Acad Sci USA 99:8968-8973, 2002.

31. Giasson BI, Duda JE, Quinn SM, Zhang B, Trojanowski JQ, Lee VM. Neuronal $\alpha$-synucleinopathy with severe movement disorder in mice expressing A53T human $\alpha$-synuclein. Neuron 34:521-533, 2002.

32. Gomez-Isla T, Irizarry MC, Mariash A, Cheung B, Soto O, Schrump S, Sondel J, Kotilinek L, Day J, Schwarzschild MA, Cha JH, Newell K, Miller DW, Ueda K, Young AB, Hyman BT, Ashe $\mathrm{KH}$. Motor dysfunction and gliosis with preserved dopaminergic markers in human $\alpha$-synuclein A30P transgenic mice. Neurobiol Aging 24:245-258, 2003.

33. Richfield EK, Thiruchelvam MJ, Cory-Slechta DA, Wuertzer C, Gainetdinov RR, Caron MG, Di Monte DA, Federoff HJ. Behavioral and neurochemical effects of wild-type and mutated human $\alpha$-synuclein in transgenic mice. Exp Neurol 175:35-48, 2002.

34. Rockenstein E, Mallory M, Hashimoto M, Song D, Shults CW, Lang I, Masliah E. Differential neuropathological alterations in transgenic mice expressing $\alpha$-synuclein from the platelet-derived growth factor and Thy-1 promoters. J Neurosci Res 68:568-578, 2002.

35. Masliah E, Rockenstein E, Veinbergs I, Mallory M, Hashimoto M, Takeda A, Sagara Y, Sisk A, Mucke L. Dopaminergic loss and inclusion body formation in $\alpha$-synuclein mice: implications for neurodegenerative disorders. Science 287:1265-1269, 2000.

36. Gispert S, Del Turco D, Garrett L, Chen A, Bernard DJ, HammClement J, Korf HW, Deller T, Braak H, Auburger G, Nussbaum RL. Transgenic mice expressing mutant A53T human $\alpha$-synuclein show neuronal dysfunction in the absence of aggregate formation. Mol Cell Neurosci 24:419-429, 2003.

37. Thiruchelvam MJ, Powers JM, Cory-Slechta DA, Richfield EK. Risk factors for dopaminergic neuron loss in human $\alpha$-synuclein transgenic mice. Eur J Neurosci 19:845-854, 2004.

38. Song DD, Shults CW, Sisk A, Rockenstein E, Masliah E. Enhanced substantia nigra mitochondrial pathology in human $\alpha$-synuclein transgenic mice after treatment with MPTP. Exp Neurol 186:158-172, 2004.

39. Fleming SM, Salcedo J, Fernagut PO, Rockenstein E, Masliah E, Levine MS, Chesselet MF. Early and progressive sensorimotor 
anomalies in mice overexpressing wild-type human $\alpha$-synuclein. J Neurosci 24:9434-9440, 2004.

40. Frey KA, Koeppe RA, Kilbourn MR, Vander Borght TM, Albin RL, Gilman S, Kuhl DE. Presynaptic monoaminergic vesicles in Parkinson's disease and normal aging. Ann Neurol 40:873-884, 1996.

41. Rinne JO, Ruottinen H, Bergman J, Haaparanta M, Sonninen P, Solin O. Usefulness of a dopamine transporter PET ligand [(18)F $] \beta$-CFT in assessing disability in Parkinson's disease. J Neurol Neurosurg Psychiatry 67:737-741, 1999.

42. Lucking CB, Durr A, Bonifati V, Vaughan J, De Michele G, Gasser T, Harhangi BS, Meco G, Denefle P, Wood NW, Agid Y, Brice A. Association between early-onset Parkinson's disease and mutations in the parkin gene. French Parkinson's Disease Genetics Study Group. N Engl J Med 342:1560-1567, 2000.

43. Hayashi S, Wakabayashi K, Ishikawa A, Nagai H, Saito M, Maruyama $\mathrm{M}$, Takahashi $\mathrm{T}$, Ozawa $\mathrm{T}$, Tsuji S, Takahashi $\mathrm{H}$. An autopsy case of autosomal-recessive juvenile parkinsonism with a homozygous exon 4 deletion in the parkin gene. Mov Disord $15: 884-888,2000$

44. Mori H, Kondo T, Yokochi M, Matsumine H, Nakagawa-Hattori Y, Miyake T, Suda K, Mizuno Y. Pathologic and biochemical studies of juvenile parkinsonism linked to chromosome 6q. Neurology 51:890-892, 1998.

45. Takahashi H, Ohama E, Suzuki S, Horikawa Y, Ishikawa A, Morita T, Tsuji S, Ikuta F. Familial juvenile parkinsonism: clinical and pathologic study in a family. Neurology 44:437-441, 1994.

46. Farrer M, Chan P, Chen R, Tan L, Lincoln S, Hernandez D, Forno L, Gwinn-Hardy K, Petrucelli L, Hussey J, Singleton A, Tanner C, Hardy J, Langston JW. Lewy bodies and parkinsonism in families with parkin mutations. Ann Neurol 50:293-300, 2001.

47. Imai Y, Soda M, Inoue H, Hattori N, Mizuno Y, Takahashi R. An unfolded putative transmembrane polypeptide, which can lead to endoplasmic reticulum stress, is a substrate of Parkin. Cell 105: 891-902, 2001.

48. Shimura H, Schlossmacher MG, Hattori N, Frosch MP, Trockenbacher A, Schneider R, Mizuno Y, Kosik KS, Selkoe DJ. Ubiquitination of a new form of $\alpha$-synuclein by parkin from human brain: implications for Parkinson's disease. Science 293:263-269, 2001.

49. Zhang Y, Gao J, Chung KK, Huang H, Dawson VL, Dawson TM. Parkin functions as an E2-dependent ubiquitin-protein ligase and promotes the degradation of the synaptic vesicle-associated protein, CDCrel-1. Proc Natl Acad Sci USA 97:13354-13359, 2000.

50. Chung KK, Zhang Y, Lim KL, Tanaka Y, Huang H, Gao J, Ross CA, Dawson VL, Dawson TM. Parkin ubiquitinates the $\alpha$-synuclein-interacting protein, synphilin-1: implications for Lewy-body formation in Parkinson disease. Nat Med 7:11441150, 2001.

51. Itier JM, Ibanez P, Mena MA, Abbas N, Cohen-Salmon C, Bohme GA, Laville M, Pratt J, Corti O, Pradier L, Ret G, Joubert C, Periquet M, Araujo F, Negroni J, Casarejos MJ, Canals S, Solano R, Serrano A, Gallego E, Sanchez M, Denefle P, Benavides J, Tremp G, Rooney TA, Brice A, Garcia de Yebenes J. Parkin gene inactivation alters behaviour and dopamine neurotransmission in the mouse. Hum Mol Genet 12:2277-2291, 2003.

52. Goldberg MS, Fleming SM, Palacino JJ, Cepeda C, Lam HA, Bhatnagar A, Meloni EG, Wu N, Ackerson LC, Klapstein GJ, Gajendiran M, Roth BL, Chesselet MF, Maidment NT, Levine MS, Shen J. Parkin-deficient mice exhibit nigrostriatal deficits but not loss of dopaminergic neurons. J Biol Chem 278:43628-43635, 2003.

53. Von Coelln R, Thomas B, Savitt JM, Lim KL, Sasaki M, Hess EJ, Dawson VL, Dawson TM. Loss of locus coeruleus neurons and reduced startle in parkin null mice. Proc Natl Acad Sci USA 101:10744-10749, 2004.

54. Perez FA, Palmiter RD. Parkin-deficient mice are not a robust model of parkinsonism. Proc Natl Acad Sci USA 102:2174-2179, 2005.

55. Palacino JJ, Sagi D, Goldberg MS, Krauss S, Motz C, Wacker M, Klose J, Shen J. Mitochondrial dysfunction and oxidative damage in parkin-deficient mice. J Biol Chem 279:18614-18622, 2004.

56. German DC, Manaye KF, White CL 3rd, Woodward DJ, McIntire
DD, Smith WK, Kalaria RN, Mann DM. Disease-specific patterns of locus coeruleus cell loss. Ann Neurol 32:667-676, 1992.

57. Sidman RL, Dickie MM, Appel SH. Mutant mice (Quaking and Jimpy) with deficient myelination in the central nervous system. Science 144:309-311, 1964.

58. Lorenzetti D, Antalffy B, Vogel H, Noveroske J, Armstrong D, Justice M. The neurological mutant quaking (viable) is Parkin deficient. Mamm Genome 15:210-217, 2004.

59. Lockhart PJ, O'Farrell CA, Farrer MJ. It's a double knock-out! The quaking mouse is a spontaneous deletion of parkin and parkin co-regulated gene (PACRG). Mov Disord 19:101-104, 2004.

60. Nikulina EM, Skrinskaya JA, Avgustinovich DF, Popova NK Dopaminergic brain system in the quaking mutant mouse. Pharmacol Biochem Behav 50:333-337, 1995.

61. Hwang DY, Fleming SM, Ardayfio P, Moran-Gates T, Kim H, Tarazi FI, Chesselet MF, Kim KS. 3,4-Dihydroxyphenylalanine reverses the motor deficits in Pitx3-deficient aphakia mice: behavioral characterization of a novel genetic model of Parkinson's disease. J Neurosci 25:2132-2137, 2005.

62. Abou-Sleiman PM, Healy DG, Quinn N, Lees AJ, Wood NW. The role of pathogenic DJ-1 mutations in Parkinson's disease. Ann Neurol 54:283-286, 2003.

63. Hague S, Rogaeva E, Hernandez D, Gulick C, Singleton A, Hanson M, Johnson J, Weiser R, Gallardo M, Ravina B, Gwinn-Hardy K, Crawley A, St George-Hyslop PH, Lang AE, Heutink P, Bonifati V, Hardy J. Early-onset Parkinson's disease caused by a compound heterozygous DJ-1 mutation. Ann Neurol 54:271-274, 2003

64. Hedrich K, Djarmati A, Schafer N, Hering R, Wellenbrock C, Weiss PH, Hilker R, Vieregge P, Ozelius LJ, Heutink P, Bonifati $\mathrm{V}$, Schwinger E, Lang AE, Noth J, Bressman SB, Pramstaller PP, Riess O, Klein C. DJ-1 (PARK7) mutations are less frequent than Parkin (PARK2) mutations in early-onset Parkinson disease. Neurology 62:389-394, 2004

65. Bandopadhyay R, Kingsbury AE, Cookson MR, Reid AR, Evans IM, Hope AD, Pittman AM, Lashley T, Canet-Aviles R, Miller DW, McLendon C, Strand C, Leonard AJ, Abou-Sleiman PM, Healy DG, Ariga H, Wood NW, de Silva R, Revesz T, Hardy JA, Lees AJ. The expression of DJ-1 (PARK7) in normal human CNS and idiopathic Parkinson's disease. Brain 127:420-430, 2004.

66. Nagakubo D, Taira T, Kitaura H, Ikeda M, Tamai K, Iguchi-Ariga SM, Ariga H. DJ-1, a novel oncogene which transforms mouse NIH3T3 cells in cooperation with ras. Biochem Biophys Res Commun 231:509-513, 1997.

67. Hod Y, Pentyala SN, Whyard TC, El-Maghrabi MR. Identification and characterization of a novel protein that regulates RNA-protein interaction. J Cell Biochem 72:435-444, 1999.

68. Mitsumoto A, Nakagawa Y. DJ-1 is an indicator for endogenous reactive oxygen species elicited by endotoxin. Free Radic Res 35:885-893, 2001.

69. Mitsumoto A, Nakagawa Y, Takeuchi A, Okawa K, Iwamatsu A, Takanezawa Y. Oxidized forms of peroxiredoxins and DJ-1 on two-dimensional gels increased in response to sublethal levels of paraquat. Free Radic Res 35:301-310, 2001.

70. Greenamyre JT, Hastings TG. Biomedicine. Parkinson's-divergent causes, convergent mechanisms. Science 304:1120-1122, 2004.

71. Yokota T, Sugawara K, Ito K, Takahashi R, Ariga H, Mizusawa H. Down regulation of DJ-1 enhances cell death by oxidative stress, ER stress, and proteasome inhibition. Biochem Biophys Res Commun 312:1342-1348, 2003.

72. Martinat C, Shendelman S, Jonason A, Leete T, Beal MF, Yang L, Floss T, Abeliovich A. Sensitivity to oxidative stress in DJ-1deficient dopamine neurons: an ES-derived cell model of primary parkinsonism. PLoS Biol 2:e327, 2004.

73. Shendelman S, Jonason A, Martinat C, Leete T, Abeliovich A. DJ-1 is a redox-dependent molecular chaperone that inhibits $\alpha$-synuclein aggregate formation. PLoS Biol 2:e362, 2004.

74. Goldberg MS, Pisani A, Haburcak M, Vortherms TA, Kitada T, Costa C, Tong Y, Martella G, Tscherter A, Martins A, Bernardi G, Roth BL, Pothos EN, Calabresi P, Shen J. Nigrostriatal dopaminergic deficits and hypokinesia caused by inactivation of the familial Parkinsonism-linked gene DJ-1. Neuron 45:489-496, 2005.

75. Kim RH, Smith PD, Aleyasin H, Hayley S, Mount MP, Pownall S, 
Wakeham A, You-Ten AJ, Kalia SK, Horne P, Westaway D, Lozano AM, Anisman H, Park DS, Mak TW. Hypersensitivity of DJ-1-deficient mice to 1-methyl-4-phenyl-1,2,3,6-tetrahydropyrindine (MPTP) and oxidative stress. Proc Natl Acad Sci USA 2005.

76. Law SW, Conneely OM, DeMayo FJ, O'Malley BW. Identification of a new brain-specific transcription factor, NURR1. Mol Endocrinol 6:2129-2135, 1992.

77. Iwawaki T, Kohno K, Kobayashi K. Identification of a potential nurr1 response element that activates the tyrosine hydroxylase gene promoter in cultured cells. Biochem Biophys Res Commun 274:590-595, 2000.

78. Sacchetti P, Mitchell TR, Granneman JG, Bannon MJ. Nurr1 enhances transcription of the human dopamine transporter gene through a novel mechanism. J Neurochem 76:1565-1572, 2001.

79. Le WD, Xu P, Jankovic J, Jiang H, Appel SH, Smith RG, Vassilatis DK. Mutations in NR4A2 associated with familial Parkinson disease. Nat Genet 33:85-89, 2003.

80. Zetterstrom RH, Solomin L, Jansson L, Hoffer BJ, Olson L, Perl- mann T. Dopamine neuron agenesis in Nurr1-deficient mice. Science 276:248-250, 1997.

81. Le W, Conneely OM, He Y, Jankovic J, Appel SH. Reduced Nurr1 expression increases the vulnerability of mesencephalic dopamine neurons to MPTP-induced injury. J Neurochem 73:2218-2221, 1999.

82. Jiang C, Wan X, He Y, Pan T, Jankovic J, Le W. Age-dependent dopaminergic dysfunction in Nurr1 knockout mice. Exp Neurol 191:154-162, 2005.

83. Nunes I, Tovmasian LT, Silva RM, Burke RE, Goff SP. Pitx3 is required for development of substantia nigra dopaminergic neurons. Proc Natl Acad Sci USA 100:4245-4250, 2003.

84. Hwang DY, Ardayfio P, Kang UJ, Semina EV, Kim KS. Selective loss of dopaminergic neurons in the substantia nigra of Pitx3deficient aphakia mice. Brain Res Mol Brain Res 114:123-131, 2003.

85. Semina EV, Murray JC, Reiter R, Hrstka RF, Graw J. Deletion in the promoter region and altered expression of Pitx 3 homeobox gene in aphakia mice. Hum Mol Genet 9:1575-1585, 2000. 